\title{
Analysing portfolio diversification opportunities in selected stock markets of North and South America and their impact on the textile sector: An empirical case study
}

DOI: 10.35530/IT.072.04.1808

RAMONA BIRAU

ELENA LOREDANA MINEA

CRISTI SPULBAR

ALI IMRAN ZULFIQAR

AJMAL HAMZA

MIHAI OVIDIU CERCEL

EJAZ ABDULLAH

\begin{abstract}
REZUMAT
Analysing portfolio diversification opportunities in selected stock markets of North and South America and their impact on the textile sector: An empirical case study
\end{abstract}

This empirical study investigates the financial integration linkages among the sample stock markets of Canada, Mexico, United States (for both New York Stock Exchange, i.e. NYSE and NASDAQ), Panama, Brazil, Chile, Peru, Venezuela, Jamaica, Trinidad, and Tobago during the period from January 2001 to April 2019. This research study also examines the impact of selected stock market dynamics on the textile sector. International portfolio diversification has been an important subject of research in financial fraternity since the emergence of Modern Portfolio Theory in 1952. This study examines the portfolio diversification opportunities in the 11 stock markets of Americas. International diversification among stock market indices has proven to be fruitful in the past. Certain tests have been used to determine opportunities for diversification are correlation test, pairwise co-integration test, multiple co-integration test and granger causality test. The empirical results show that stock market indices share low correlation among other and they are not highly co-integrated whereas results of Granger causality test exhibit an unidirectional relationship among few stock markets in short run.

Keywords: portfolio diversification strategy, co-integration, textile industry, Granger causality test, correlation coefficient, modern portfolio theory

Analiza oportunităților de diversificare a portofoliului pe piețele bursiere selectate din America de Nord și de Sud, precum și impactul acestora asupra sectorului textil: Un studiu de caz empiric

Acest studiu empiric investighează integrarea financiară existentă între piețele bursiere incluse în clusterul format din Canada, Mexic, Statele Unite ale Americii (atât pentru piața bursieră din New York, adică pentru NYSE, cât și pentru NASDAQ), Panama, Brazilia, Chile, Peru, Venezuela, Jamaica, Trinidad și Tobago pentru intervalul de timp ianuarie 2001 - aprilie 2019. De asemenea, acest studiu de cercetare analizează impactul dinamicii piețelor bursiere selectate asupra sectorului textil. Diversificarea portofoliului internațional a fost un subiect important de studiu în domeniul financiar, încă de la apariția teoriei moderne a portofoliului în 1952. Studiul analizează oportunitățile de diversificare a portofoliului pe cele 11 piețe bursiere din America. Diversificarea internațională aplicată cu ajutorul indicilor bursieri s-a dovedit a fi profitabilă în trecut. Anumite teste au fost utilizate pentru a determina oportunitățile de diversificare, respectiv: testul de corelație, testul de cointegrare pereche, testul de cointegrare multiplă și testul de cauzalitate Granger. Rezultatele empirice evidențiază faptul că indicii bursieri analizați prezintă o corelație scăzută și nu există o relație puternică de cointegrare, în timp ce rezultatele testului de cauzalitate Granger prezintă relația unidirecțională manifestată între câteva piețe bursiere pe termen scurt.

Cuvinte cheie: strategia de diversificare a portofoliului, cointegrare, industria textilă, testul de cauzalitate Granger, coeficientul de corelație, teoria modernă a portofoliului

\section{INTRODUCTION}

Portfolio diversification among the global stock markets has long been a prominent practice among investors to diversify and minimize portfolio risk and maximize stock returns. It has also been a topic of continuous academic research to examine the integration among stock markets of various countries to see whether they provide diversification opportunity to investors or not. Stock markets that are segmented provide better opportunity of diversification as compared to stock markets that are integrated with each other $[1,2]$. There have been studies that measure the integration of developed financial markets with developed markets [1], developed with emerging markets [3], emerging markets with emerging markets [4] and integration of regional financial markets [2]. Moreover, Spulbar et al. [5] investigated volatility spill over patterns between selected emerging 
(Hungary, Romania, China, Poland and India) and developed (USA, UK, France, Canada, Spain, Germany and Japan) stock markets.

The Americas include countries from the continents of North and South America. This study examines the integration among the sample stock markets of Canada, Mexico, United States (for both New York Stock Exchange (NYSE) and NASDAQ), Panama, Brazil, Chile, Peru, Venezuela, Jamaica, Trinidad, and Tobago during the period from January 2001 to April 2019. The chosen sample allows us to examine the stock market integration among the markets that are in a similar geographical region but differ greatly in regulatory setting and are in various stages of development. For example, the NYSE and the NASDAQ are the largest first and the second largest stock markets in the world in terms of market capitalization and have been a focus of enormous research due to the US being a major investor in many countries, enforces a huge political influence on several countries in the world and is an important factor in influencing the world financial markets. The US market is also found to be a leading the world stock markets while Singh et al. [2] show that little diversification opportunities exist among the regional markets as their stock market movements are highly correlated. $\mathrm{Xu}$ et al. [6] suggested that US represents the most important textile import market in the world, but also one of the most important export targets of developing countries. Textile production is the result of long manufacturing and wet-processing stages [7], while these particular manufacturing steps include yarn, fabric and garments manufacturing and wet processing [8]. However, the textile sector is influenced by the dynamics of stock markets, especially in the case of developing countries. Olaru et al. [9] argued that competitive pressure of globalization is causing textile and garment manufacturers to lower production costs, increase their efficiency and to create leaner value-adding processes. For instance, Săliştean et al. [10] argued that risk operations aim at mitigating emergency situations but are only implemented when needed considering decision making in emergency response.

Our index level data were non-stationary therefore we used co-integration vector autoregression (VAR) lag length selection criteria to examine the interdependencies among the sample stock market indices. Similar to previous studies, we find that the two stock exchanges in the US (i.e. the NYSE and the NAS$D A Q)$ are highly integrated hence they do not provide a diversification opportunity. However, diversification opportunities exist among the other stock exchanges irrespective of their regional proximity or the level of market development. For example, the stock markets of Peru and Trinidad and Tobago, and Mexico and Panama are negatively correlated and provide fruitful diversification opportunities. Contrary to the results of previous studies [4], our results suggest that stock markets in North and South Americas present potential opportunities for diversification.

\section{LITERATURE REVIEW}

The modern portfolio theory by Markowitz [11] suggests that portfolio diversification can reduce the investment risk but the extent of which depends upon the correlations among the returns of the securities in the portfolio. The correlations between economies tend to move in unison. Levy and Sarnat [12] suggest that portfolios should be diversified internationally to avoid country specific risk. Grubel and Fadner [13] argue that investors tend to invest in stocks of foreign countries to avoid the effect of domestic business cycles and government policies. The era of 1970's experienced the start of globalization with changes in technology and innovations in financial markets. As a result, the trend of taking advantage from cross border diversification increased. This led the investors to diversify their portfolios by investing in the stocks of foreign countries. Also, investors may earn capital gain due to exchange rate fluctuations. World Bank reported in 1997 that the financial markets of world were becoming global market places where investors diversify their portfolios among various developing countries to minimize risk and achieve higher returns. It is argued that an internationally diversified portfolio has risk less than half of the risk of the portfolio that consists of the US based securities only [14]. On the other hand, Yildirim and Masih [15] suggested that if the emerging stock markets were fully integrated with the developed stock markets, there would not be any portfolio diversification benefit for either the developed and/or the emerging countries' investors.

The focus of many studies, have been on examining the causal relationship between United States and stock markets of other countries [16]. Reason being; the US has been a major investor in many countries and enforces a huge political influence on several countries in the world. Results of these studies show that the United States has been an important global factor that moved the world markets. Maldonado and Saunders [16] examined inter-temporal patterns of the correlation coefficients between monthly returns on United States stock index with monthly returns on indices of Canada, Germany, Japan and United Kingdom over a period of 22 years from 1957 to 1978. They concluded that a predictable relationship exists between these countries in short run. However, in the long-run, there are unstable correlations among the sample stock markets. While Bessler and Yang [1] add that, although the US markets lead, the US markets are also influenced by the UK, Switzerland, Hong Kong, France and Germany. These results may not be as surprising given the rate of integration of the world economy with the US economy. They further argue that the international financial markets are neither fully integrated, not fully segmented implying a potential opportunity for international diversification.

Various studies have been conducted to examine the integration of various stock markets across the world. Ripley [18] investigated the systematic covariance between stock prices of nineteen developed stock 
markets of the world. He explored the relationship between the stock prices using factor analysis and found that more than half of the movement in stock prices of a country is unique from other countries. Panton, Parker and Joy [19] examined the relationship between the weekly stock prices of twelve developed countries by applying cluster analysis over the period from 1963 to 1972 . The results showed relatively strong relationship between stock markets of Canada, Netherlands, Switzerland, Belgium and the United States. However, less strong relationship existed between Germany and Netherlands, France and Belgium, and England and Australia.

Similarly, other researchers such as Trivedi et al. [20] investigated volatility spill overs and co-movements based on a cluster of European stock markets, such as developed (Spain, UK, Germany, and France) and emerging (Poland, Hungary, Croatia, and Romania) from January 2000 to July 2018. Arshanapalli and Doukas [21] analysed the stock markets of Japan, United Kingdom, France, Germany and the United States for the period from January 1980 to May 1990 using daily closing market index. They found that the interdependence among world capital markets have increased since the 1987 stock market crash, apart from Japan's Nikkei Index. Corhay, Rad and Urbain [22] examined the stock markets of Australia, Singapore, Japan, Hong Kong and New Zealand over the period from 1972 to 1992 and found that there is no evidence of a single stochastic trend among the sample countries. Cheung and Mak [23] examined the causal relationship between the emerging markets of Asia with the developed markets of the US and Japan. They found that emerging Asian markets are led by the United States Stock market except the stock markets of Korea, Taiwan and Thailand whereas Japanese market has less influence on emerging markets of Asia Pacific region. DeFusco et al. [24] examined the co-integration among US and emerging Asian stock markets of Thailand, Malaysia, Hong Kong, Taiwan, Korea, Singapore, and the Philippines in the 1980s and early 1990s and found that there is no integration between these emerging markets of Asia and the US. Korajczyk [25] tried to find relationship between twenty-four markets of the world and found that emerging markets are more segmented as compared to developed markets providing an opportunity of diversification.

Ghosh, Saidi, and Johnson [26] applied the theory of co-integration using daily closing values of stock market indices to investigate which stock markets of Asia Pacific are moved by the markets of Japan and the United States He found that stock markets of India, Hong Kong, Malaysia and Korea share a longrun equilibrium relationship with stock markets of the United States, while the stock markets of Singapore, Indonesia and Philippines are linked with the stock market of Japan. However, the stock markets of Taiwan and Thailand are not influenced by the stock markets of United States and Japan. Tuluca and Zwick [27] studied the stock indices difference by applying Granger-causality technique. He used factor analysis to study the stock indices returns before and after the Asian financial crises of 1997 among thirteen Asian and non-Asian stock markets. They concluded that the co-movement among these markets is stronger after the Asian financial crises of 1997. Wong et al. [28] measured the integration between stock markets of developed countries and emerging Asian markets. They found that the integration between these countries has increased after the 1987 stock market crash. This integration has increased even more after the 1997 Asian financial crisis.

Antonio [29] examined long run relationship among the stock markets of European region using co integration techniques and found no evidence of long run relationship between these countries' stock markets. Using co-integration analysis and error correction vector autoregressions (VAR) techniques to model the interdependencies on stock market indices of Latin American stock markets, Chen, Firth, and Rui [4] find limited potential for diversifying risk in those markets. On the other hand, using partial correlationbased networks to estimate the linkages between global equity markets Singh, Li, and Roca [2] show that regional markets are more correlated while the negative correlations exist in global markets providing diversification opportunities.

\section{EMPIRICAL METHODOLOGY AND STATISTICAL DATA}

This section contains the data and methodology. Data for 11 stock markets from 10 countries on the American continent have been downloaded from data stream. These countries are Canada, Mexico, USA (NASDAQ and NYSE), Panama, Brazil, Chile, Peru, Venezuela, Jamaica and Trinidad and Tobago. Stock market indices have been downloaded from 11 stock markets. The stock market indices are the following: S\&P/TSX Composite Index (Canada), Mexico IPC (Mexico), NASDAQ Composite (USA), NYSE Composite (USA), PANAMA SE BVPSI (Panama), Brazil BOVESPA (Brazil), S\&P/CLX IGPA CLP INDEX (Chile), S\&P/BVL GENERAL(IGBVL), VENA, MERINVEST Composite (Venezuela), Jamaica SE main index (Jamaica) and S\&P Trinidad \& Tobago BMI (Trinidad and Tobago). Daily stock market indices have been downloaded for 11 stock markets from data stream. Time period of the data started from $3^{\text {rd }}$ of January 2001 and ended on $30^{\text {th }}$ of April 2019.

To examine the diversification opportunities among the stock markets, results of pairwise correlation, multiple and pairwise co-integration and causality integration will be examined.

Details of these tests are as follows:

Correlation Matrix measures the tandem movements of two stock indices in terms of dependency. It determines if two stock stocks are independent or dependent upon each other or not. Its value is from +1 to -1 which is called correlation coefficient. 
Whereas, positive 1 correlation coefficient indicates that movements are tandem between two stocks and negative 1 correlation coefficient indicates that movements of two stock indices are not tandem and 0 correlation coefficient means that there is no relationship between two stock market indices. Correlation is a trivial part of global portfolio diversification and investors are recommended to diversify among stock market indices that have low correlation coefficient between them.

Variance of a portfolio is measured using following equation:

$$
\sigma^{2} p=\omega^{2} A \sigma^{2} A+\omega^{2} \sigma^{2} B+2 \omega A \omega B \sigma A \sigma B \rho A B
$$

where $\sigma^{2} p$ is variance of portfolio, $\omega^{2} A$ - weight of a security in portfolio and $\rho$-correlation coefficient.

Unit Root Test examines stationarity of a time series which characterizes stock market index is examined to run co-integration. Time series should be stationary at first level in order to run co-integration. According to Fama [30], stock prices reflect all available information in efficient market hypothesis $(\mathrm{EMH})$. The author categorized stock market into week form $\mathrm{EMH}$, semi-string form $\mathrm{EMH}$ and strong form EMH. In week form EMH, stock prices are nonstationary displaying a "fad" in the movements of stock prices. Unit root test is applied to check the stationarity of the data. Dickey Fuller test is used to examine stationarity through unit root test. The results of unit root test may display random walk in time series showing inefficiency in the stock market indices. The null hypothesis of unit root test is that data is nonstationary.

$$
y_{t}=\rho y_{t-1}+\mu_{t}
$$

where $y_{t}$ is stock market index for a given day, $y_{t-1}-$ stock market index for previous day, $\rho$ - coefficient and $\mu_{t}$ - error term.

\section{Johansen's multivariate co-integration test}

If two or more indices have tandem movements, they are integrated with each other. Johansen's co-inte- gration test is used to examine the tandem movements among stock market indices. It will be used to examine the long run and short run relationship among stock market indices. Following function will be used to examine multivariate co-integration among stock market indices:

$$
\lambda \text { trace }=-T \sum \ln (1-\lambda \mathrm{i})
$$

where $\lambda i$ is estimated Eigen value and $\lambda$ trace is trace statistic.

\section{Granger causality test}

Granger causality test examines the impact of one market index on the other. The relationship between market indices can unidirectional or bidirectional. Unidirectional relationship means only one index is impacting the other index and bidirectional relationship means both indices are impacting each other.

\section{EMPIRICAL RESULTS}

The following table displays the descriptive statistics for selected 11 stock market indices. Total number of observations is 5042 . The highest mean value is posted by Venezuela stock market which is $0.392 \%$ whereas the lowest mean value is $0.0190 \%$ posted by Canadian stock market. Highest standard deviation value means that stock market is extremely volatile. Venezuela stock market is a highly volatile market because of its high standard deviation value which is 8.2 whereas least volatile stock market is Trinidad and Tobago which is 0.69 . It is interesting to note that Venezuelan stock market posts the highest mean return and it is also the most volatile stock market in the sample. The lowest minimum return is posted by Venezuela stock market which is $-97.63 \%$ whereas highest "minimum" return is posted by Jamaican stock market. Lowest "maximum" return is posted by Jamaica which is $8.28 \%$. Whereas highest maximum return is posted by Venezuela stock market which $498 \%$. It is important to observe that Venezuela stock market is the one with highest mean

\begin{tabular}{|c|c|c|c|c|c|c|}
\hline \multicolumn{7}{|c|}{ DESCRIPTIVE STATISTICS } \\
\hline SI. no. & Country & Obs. & Mean & Std. Dev. & Min & Max \\
\hline 1 & Canada & 5042 & 0.019075 & 1.058215 & -9.32419 & 9.823324 \\
\hline 2 & Mexico & 5042 & 0.044235 & 1.255072 & -7.93483 & 11.00523 \\
\hline 3 & NASDAQ & 5042 & 0.025638 & 1.549943 & -9.66851 & 14.1732 \\
\hline 4 & NYSE & 5042 & 0.019589 & 1.170759 & -9.726 & 12.21624 \\
\hline 5 & Panama & 5042 & 0.027358 & 0.663432 & -12.647 & 14.56904 \\
\hline 6 & Brazil & 5042 & 0.049143 & 1.722829 & -11.3931 & 14.65784 \\
\hline 7 & Chile & 5042 & 0.034988 & 0.733261 & -5.80357 & 9.480726 \\
\hline 8 & Peru & 5042 & 0.056721 & 1.30034 & -12.4454 & 13.67299 \\
\hline 9 & Venezuela & 5042 & 0.392427 & 8.230275 & -97.6399 & 498.2278 \\
\hline 10 & Jamaica & 5042 & 0.060879 & 0.795577 & -6.12349 & 8.282775 \\
\hline 11 & S\&P Trinidad \& Tobago & 5042 & 0.025458 & 0.694279 & -7.7563 & 15.90086 \\
\hline
\end{tabular}




\begin{tabular}{|c|c|c|c|c|c|c|c|c|c|c|c|}
\hline \multicolumn{12}{|c|}{ CORRELATION MATRIX } \\
\hline Country & Canada & Mexico & $\begin{array}{c}\text { USA } \\
\text { (NASDAQ) }\end{array}$ & $\begin{array}{l}\text { USA } \\
\text { (NYSE) }\end{array}$ & Panama & Brazil & Chile & Peru & Venezuela & Jamaica & $\begin{array}{c}\text { Trinidad \& } \\
\text { Tobago }\end{array}$ \\
\hline Canada & 1 & & & & & & & & & & \\
\hline Mexico & 0.5815 & 1 & & & & & & & & & \\
\hline $\begin{array}{l}\text { USA } \\
\text { (NASDAQ) }\end{array}$ & 0.6705 & 0.6171 & 1 & & & & & & & & \\
\hline $\begin{array}{l}\text { USA } \\
\text { (NYSE) }\end{array}$ & 0.743 & 0.6579 & 0.8128 & 1 & & & & & & & \\
\hline Panama & -0.0172 & -0.0184 & -0.0237 & -0.0304 & 1 & & & & & & \\
\hline Brazil & 0.5506 & 0.5952 & 0.5257 & 0.6055 & -0.002 & 1 & & & & & \\
\hline Chile & 0.4331 & 0.4681 & 0.3663 & 0.4706 & -0.0089 & 0.4618 & 1 & & & & \\
\hline Peru & 0.4429 & 0.3817 & 0.3064 & 0.4237 & 0.0235 & 0.3961 & 0.4098 & 1 & & & \\
\hline Venezuela & 0.0035 & 0.031 & 0.016 & 0.01 & 0.0268 & 0.0222 & 0.018 & 0.0205 & 1 & & \\
\hline Jamaica & 0.0429 & 0.0343 & 0.014 & 0.0311 & 0.0075 & 0.0289 & 0.0313 & 0.0394 & 0.0045 & 1 & \\
\hline $\begin{array}{l}\text { Trinidad \& } \\
\text { Tobago }\end{array}$ & 0.0132 & 0.0042 & 0.0065 & 0.0145 & 0.0102 & 0.0211 & 0.021 & -0.0062 & -0.0004 & 0.0217 & 1 \\
\hline
\end{tabular}

return and it is also highly volatile (highest standard deviation value) whereas it also posts lowest and highest returns.

Table 2 includes the empirical results for the correlation matrix. The correlation coefficient displays if two sectors are independent or not? If yes, their movements are tandem or not. The correlation coefficient values show if the relationship between two stock market indices exists, if yes, then the relationship is strong or weak? The correlation coefficient value varies from +1 to -1 . Moreover, +1 value indicates that two indices are dependent upon each other and share a strong relationship whereas -1 value indicates that there is no relationship or extremely weak relationship between two indices and two stock market indices do not dependent upon each other and their movements are not tandem.

Rahim and Masih [31] used correlation coefficient to examine the relationship between Islamic stocks and their trading partners for portfolio diversification. You and Daigler [32], Engle and Sheppard [33] and Capiello et al. [34] also used correlation coefficient in this regard. It is clear from the correlation coefficient results that all stock market indices do not strong correlation coefficient with each other except for two stock market indices from US whereas some stock market indices share negative correlation. NYSE and NASDAQ post highest correlation coefficient in the table which is $0.81 \%$. It means that both stock market indices are dependent upon each other and their relationship is strong. Their price movements are in tandem. An increase in NYSE index will lead to an increase in NASDAQ index and vice versa. However, rest of the market indices share low correlation hence the relationship between them is weak. For instance, Canada's stock market index correlation coefficient with NYSE and NASDAQ is 0.67 and 0.74 respectively which shows that its relationship is weak and price movements of these indices are not tandem and they do not dependent upon each other. Canada and Panama share the weak and negative relationship. For instance, correlation coefficient of between Canada and Panama is -0.0172 which shows that they are independent of each other and their price movements are not tandem. Similar trend can be observed throughout the table.

In order to run co-integration time series must be stationary at the same level. If data i.e. stock market index is not stationary, then there will be a growth value in the time series. Therefore, all stock market indices in the data must be stationary at same level in order to run co-integration test. Dickey Fuller test is applied to examine the time series for stationarity at level (0). Bouri et al. [35] examined co-integration among India stock market and gold and oil sector and applied Dickey Fuller test to inspect for stationarity in the time series. Cheong [36] examined the weak form efficiency of stock market using unit root test. Alamet al. [37] applied stationarity test to examine the sectoral efficiency of Islamic stock indices. Moreover, Spulbar and Birau [38] examined the behaviour of selected emerging stock markets in Romania, Poland, Hungary and India but the empirical analysis results rejected efficient market hypothesis. On the other hand, Zulfiqar et al. [39] suggested that governance quality positively affects financial markets in the case of developed countries. Null hypothesis of Dickey Fuller test states that there is a unit root in the data which means that data is not stationary. For data to be stationary at $1 \%$ significance level with -3.430 as critical value, t-stat value must be less than -3.430 with $p$ value less than $5 \%$. Table 3 suggests that each t-stat value for each stock market index in the data is greater than critical value at $1 \%$ significance level leading to the interpretation that null hypothesis cannot be rejected and all stock market indices have unit 


\begin{tabular}{|c|c|c|c|c|c|c|c|}
\hline \multicolumn{8}{|c|}{ STATIONAIRTY CHECK: UNIT ROOT TEST AT LEVEL 0 AND LEVEL 1} \\
\hline \multirow{2}{*}{ Country } & \multirow{2}{*}{$\begin{array}{l}1 \% \text { Critical } \\
\text { value }\end{array}$} & \multicolumn{2}{|c|}{ Level 0} & \multirow{2}{*}{ Remarks } & \multicolumn{2}{|c|}{ Level 1} & \multirow{2}{*}{ Remarks } \\
\hline & & t-stat & prob. & & t-stat & prob. & \\
\hline Canada & -3.43 & -1.198 & 0.6745 & Non Stationary & -70.735 & 0 & Stationary \\
\hline Mexico & -3.43 & -1.004 & 0.7517 & Non Stationary & -66.141 & 0 & Stationary \\
\hline USA (NASDAQ) & -3.43 & 0.958 & 0.9938 & Non Stationary & -71.897 & 0 & Stationary \\
\hline USA (NYSE) & -3.43 & -0.725 & 0.8401 & Non Stationary & -74.44 & 0 & Stationary \\
\hline Panama & -3.43 & -0.271 & 0.9295 & Non Stationary & -93.846 & 0 & Stationary \\
\hline Brazil & -3.43 & -0.528 & 0.8865 & Non Stationary & -73.449 & 0 & Stationary \\
\hline Chile & -3.43 & -0.357 & 0.917 & Non Stationary & -60.494 & 0 & Stationary \\
\hline Peru & -3.43 & -0.948 & 0.7718 & Non Stationary & -62.828 & 0 & Stationary \\
\hline Venezuela & -3.43 & 2.803 & 1 & Non Stationary & -47.914 & 0 & Stationary \\
\hline Jamaica & -3.43 & 5.646 & 1 & Non Stationary & -67.778 & 0 & Stationary \\
\hline Trinidad \& Tobago & -3.43 & -1.884 & 0.3395 & Non Stationary & -71.404 & 0 & Stationary \\
\hline
\end{tabular}

Note: $1 \%$ Critical value $=-3.430$

root which means that data is not stationary at level (0).

Dickey Fuller test is run to examine the stationarity at level (1) for the 11 stock market indices. To reject null hypothesis and for data to be stationarity, $t$ stat value should be less than critical value of -3.430 at $1 \%$ level of significance. It is clear from table 3 that t-stat value of each stock market index is less than critical value with $p$ value equal to zero which leads to a conclusion that data has no unit root thus rejecting null hypothesis. Therefore, 11 stock market indices are stationary at first order difference (1).

From the results included in table 4, we can observe that the lag length number is determined. Leg length number is necessary to run co-integration and granger causality test. VAR lag length selection test has been applied to determine lag length for co-integration and granger causality test. Five methods are used by this test to in this regard. These five methods are LR test Statistics, Final Predication Error, Akaike information criterion, Schwarz Bayesian information criterion and Hannan-Quinn information criterion. It is clear from the table that three tests are supporting lag length 3 whereas two tests are supporting lag length 2. Rule of thumb in quantitative research is that lag length supported by maximum number of tests is chosen for the purpose of co-integration and granger causality test. Therefore, lag length 3 has been selected to run the co-integration and granger causality test.

Multivariate co-integration exhibits if there is integration among stock market indices or not. In order to examine if there is multivariate co-integration, Eigen value or trace statistics value is monitored (table 5). Null hypothesis of trace statistics is that there is no co-integration among stock market indices whereas alternate hypothesis is that minimum one co-integration equation exists. Like trace statistics, there is a null hypothesis for Eigen value which states that there is no co-integration however its alternate hypothesis is different i.e. there is only one co-integration equation which makes it weaker than trace statistics test. Therefore, for multivariate co-integration test, trace statistics test is used because it is more powerful than Eigen value test because this study deals with more than one co-integration equations.

Trace statistics value should be less than the critical value of any given rank value. Value with the star sign $\left.{ }^{*}\right)$ shows that there is integration among indices and rank represents the number of co-integrated equations. The table shows that at rank 3 there exists

VAR LAG LENGTH SELECTION CRITERIA

\begin{tabular}{|c|c|c|c|c|c|c|c|c|}
\hline Lag & LL & LR & df & $\mathbf{p}$ & FPE & AIC & HQIC & SBIC \\
\hline 0 & -47165.1 & & & & $7.90 E+06$ & 18.7241 & 18.7246 & 18.7254 \\
\hline 1 & -31044.6 & 32241 & 1 & 0 & 13188.6 & 12.325 & $12.325^{*}$ & $12.3276^{*}$ \\
\hline 2 & -31044.6 & 0.07693 & 1 & 0.782 & 13193.6 & 12.3254 & 12.3267 & 12.3293 \\
\hline 3 & -31041.8 & $5.6877^{*}$ & 1 & 0.017 & $13184^{*}$ & $12.324^{*}$ & 12.3264 & 12.3298 \\
\hline 4 & -31041.8 & 0.00088 & 1 & 0.976 & 13189.2 & 12.325 & 12.3273 & 12.3315 \\
\hline
\end{tabular}

Note: * indicates lag order selected by the criterion. 
MULTIVARIATE JOHANSEN'S CO-INTEGRATION TESTS

\begin{tabular}{|c|c|c|c|c|c|}
\hline $\begin{array}{c}\text { Maximum } \\
\text { rank }\end{array}$ & Parameters & LL & Eigen value & Trace statistic & 5\% critical value \\
\hline 0 & 253 & -319805 & 0 & 370.0949 & 277.71 \\
\hline 1 & 274 & -319756 & 0.01924 & 272.1873 & 233.13 \\
\hline 2 & 293 & -319720 & 0.01427 & 199.7528 & 192.89 \\
\hline 3 & 310 & -319691 & 0.01149 & $141.5095^{*}$ & 156 \\
\hline 4 & 325 & -319670 & 0.00812 & 100.419 & 124.24 \\
\hline 5 & 338 & -319652 & 0.00723 & 63.8317 & 94.15 \\
\hline 6 & 349 & -319640 & 0.00493 & 38.9122 & 68.52 \\
\hline 7 & 358 & -319632 & 0.00317 & 22.9323 & 47.21 \\
\hline 8 & 365 & -319626 & 0.0023 & 11.3243 & 29.68 \\
\hline 9 & 370 & -319622 & 0.00149 & 3.814 & 15.41 \\
\hline 10 & 373 & -319620 & 0.00075 & 0.0093 & 3.76 \\
\hline 11 & 374 & -319620 & 0 & - & - \\
\hline
\end{tabular}

Note: * indicates co-integrated equations.

co-integration. Trace statistics value is statistically significant at $5 \%$ level of significance and its less than critical value of rank 3 . It means that at least 3 co-integration equations exist in this study. It means that some market indices are co-integrated with each other. The upside of multivariate Johansen's co-inte- gration test is that it shows number of co-integration equations, but it does not exhibit the names of the cointegrated time series. To resolve this shortcoming, pairwise co-integration has been run.

Table 6 includes the empirical results on pairwise cointegration. Pairwise co-integration examines market

\begin{tabular}{|c|c|c|c|c|c|c|c|c|c|c|}
\hline \multicolumn{11}{|c|}{ PAIRWISE CO-INTEGRATION } \\
\hline Country & Canada & Mexico & $\begin{array}{c}\text { USA } \\
\text { (NASDAQ) }\end{array}$ & $\begin{array}{c}\text { USA } \\
\text { (NYSE) }\end{array}$ & Panama & Brazil & Chile & Peru & Venezuela & Jamaica \\
\hline \multirow{2}{*}{ Mexico } & $8.9126^{*}$ & & & & & & & & & \\
\hline & 0 & & & & & & & & & \\
\hline \multirow{2}{*}{$\begin{array}{l}\text { USA } \\
\text { (NASDAQ) }\end{array}$} & $10.9677^{*}$ & $13.7620^{*}$ & & & & & & & & \\
\hline & 0 & 0 & & & & & & & & \\
\hline \multirow{2}{*}{$\begin{array}{l}\text { USA } \\
\text { (NYSE) }\end{array}$} & $7.5111^{*}$ & $7.5632^{*}$ & $11.1370^{*}$ & & & & & & & \\
\hline & 0 & 0 & 0 & & & & & & & \\
\hline \multirow{2}{*}{ Panama } & $11.5014^{*}$ & $0.5480 *$ & $11.8242^{*}$ & $5.3700^{*}$ & & & & & & \\
\hline & 0 & 1 & 0 & 0 & & & & & & \\
\hline \multirow{2}{*}{ Brazil } & $5.8712^{*}$ & $3.2170^{*}$ & $7.9450^{*}$ & $2.6678^{*}$ & $13.4753^{*}$ & & & & & \\
\hline & 0 & 0 & 0 & 0 & 0 & & & & & \\
\hline \multirow{2}{*}{ Chile } & $6.7613^{*}$ & $5.3808^{*}$ & $11.1143^{*}$ & $4.7403^{*}$ & $0.3163^{*}$ & $7.2288^{*}$ & & & & \\
\hline & 0 & 0 & 0 & 0 & 1 & 0 & & & & \\
\hline \multirow{2}{*}{ Peru } & $5.8899^{*}$ & $4.7207^{*}$ & $7.4665^{*}$ & $3.2230^{*}$ & $1.2035^{*}$ & $7.4111^{*}$ & $6.0292^{*}$ & & & \\
\hline & 0 & 0 & 0 & 0 & 1 & 0 & 0 & & & \\
\hline \multirow{2}{*}{ Venezuela } & $5.0403^{*}$ & $4.4716^{*}$ & $11.2019^{*}$ & $5.9372^{*}$ & $10.2282^{*}$ & $7.5707^{*}$ & $3.9638^{*}$ & $3.0769^{*}$ & & \\
\hline & 0 & 0 & 0 & 0 & 0 & 0 & 0 & 0 & & \\
\hline \multirow{2}{*}{ Jamaica } & $3.4171^{*}$ & $0.2816^{*}$ & $3.7411^{*}$ & $2.3631^{*}$ & $0.0606^{*}$ & $3.0098^{*}$ & $1.0015^{*}$ & $1.9470 *$ & 42.5338 & \\
\hline & 1 & 1 & 1 & 1 & 1 & 1 & 1 & 1 & $n / s$ & \\
\hline \multirow{2}{*}{$\begin{array}{l}\text { Trinidad \& } \\
\text { Tobago }\end{array}$} & $8.1431^{*}$ & $6.0598^{*}$ & $9.0300^{*}$ & $6.2334^{*}$ & $4.8608^{*}$ & $4.9229^{*}$ & $5.3160^{*}$ & $8.6180^{*}$ & $4.9057^{*}$ & $3.4737^{*}$ \\
\hline & 0 & 0 & 0 & 0 & 0 & 0 & 0 & 0 & 0 & 1 \\
\hline
\end{tabular}

Note: $5 \%$ for rank $(0)$ critical value $=15.41$, for rank (1) critical value $=3.76,(0)$ indicates no co-inetgration, (1) indicates co-integration; where $\mathrm{n} / \mathrm{s}$ stands for Not Significant. 


\begin{tabular}{|l|c|c|c|c|c|c|c|c|c|c|c|}
\hline \multicolumn{10}{|c|}{ GRANGER CAUSALITY TEST-EXCLUDED SECTORS } \\
\hline \multicolumn{1}{|c|}{ Country } & Canada & Mexico & $\begin{array}{c}\text { USA } \\
\text { (NASDAQ) }\end{array}$ & $\begin{array}{c}\text { USA } \\
\text { (NYSE) }\end{array}$ & Panama & Brazil & Chile & Peru & Venezuela & Jamaica & $\begin{array}{c}\text { Trinidad \& } \\
\text { Tobago }\end{array}$ \\
\hline Canada & $19.493^{*}$ & 0.63724 & 3.3901 & $19.406^{*}$ & 4.927 & 2.6133 & $7.2992^{*}$ & 0.99557 & $7.8805^{*}$ & $20.062^{*}$ & \\
\hline Mexico & $6.355^{*}$ & & 1.5127 & 1.291 & $9.2047^{*}$ & $29.757^{*}$ & $27.819^{*}$ & $9.5616^{*}$ & 10.114 & $30.201^{*}$ & 2.7863 \\
\hline $\begin{array}{l}\text { USA } \\
\text { (NASDAQ) }\end{array}$ & $10.473^{*}$ & 3.2135 & & 0.62668 & 2.0416 & 1.0447 & 2.7732 & $22.243^{*}$ & $2.7812^{*}$ & $12.819^{*}$ & 0.89365 \\
\hline $\begin{array}{l}\text { USA } \\
\text { (NYSE) }\end{array}$ & $11.263^{*}$ & $23.543^{*}$ & 2.2704 & & $18.17^{*}$ & $20.025^{*}$ & $14.399^{*}$ & 2.3267 & 3.809 & $9.3603^{*}$ & $17.121^{*}$ \\
\hline Panama & $7.5846^{*}$ & $14.886^{*}$ & $6.2242^{*}$ & 1.5837 & & 3.4298 & 3.4629 & 4.9913 & 9.2375 & $25.621^{*}$ & 1.0997 \\
\hline Brazil & 1.9482 & $10.764^{*}$ & 1.087 & $9.5832^{*}$ & 1.1451 & & 0.91882 & $11.683^{*}$ & 2.0039 & 1.6372 & 1.4061 \\
\hline Chile & 2.9862 & 1.0867 & 1.1275 & 0.24387 & 9.0103 & $4.1031^{*}$ & & $14.925^{*}$ & 6.2731 & 0.44037 & 1.5386 \\
\hline Peru & 5.4972 & 0.23746 & 0.58877 & 2.9539 & $18.94^{*}$ & 5.2522 & $8.0175^{*}$ & & 2.1752 & 0.69496 & $13.253^{*}$ \\
\hline $\begin{array}{l}\text { Venezuela } \\
1.7422\end{array}$ & $8.259^{*}$ & 5.9118 & 2.4076 & $7.9353^{*}$ & $13.673^{*}$ & 2.3829 & 3.3397 & & $12.019^{*}$ & 0.83844 \\
\hline Jamaica & 0.6894 & $21.264^{*}$ & $11.232^{*}$ & $7.8712^{*}$ & 5.5665 & $35.882^{*}$ & $29.885^{*}$ & $7.9598^{*}$ & $25.735^{*}$ & & $21.043^{*}$ \\
\hline $\begin{array}{l}\text { Trinidad \& } \\
\text { Tobago }\end{array}$ & $11.618^{*}$ & 1.1076 & 3.6731 & 3.164 & 5.2051 & 2.9566 & $9.7358^{*}$ & $15.719^{*}$ & 2.8015 & 3.4225 & \\
\hline
\end{tabular}

Note: * indicates value is significant at $5 \%$ and excluded sector causes equation sector.

indices for integration on one to one basis. The decision of co-integration is based on trace statistics with critical value of 15.41 at $5 \%$ level of significance. If the critical value of trace statistics is less than critical value, it means that there is no co-integration. It its value is greater than critical value, it means that there is co-integration among two market indices. The results from the table 6 exhibit that all values are statistically significant except Venezuela and Jamaica. The results show that most of the market indices are not co-integrated with each other which mean that they present an excellent diversification opportunity because movement in index will not affect the movement in other market index. However, market index of Jamaica does not present diversification opportunities because it is highly co-integrated with all market indices. Similarly, market indices of Mexico and Panama are highly co-integrated. The other stock market indices which are highly co-integrated are Panama and Chile and Panama and Peru which means that there are no diversification opportunities between the market indices of Panama and Chile and Panama and Peru. Canadian stock market index is not co-integrated with any of the market indices apart from stock market index of Jamaica. Similar trend can be observed with all other countries. It is evident from the table that there are excellent diversification opportunities in stock market of Americas included in the sample.

Table 7 presents the Granger Causality TestExcluded Sectors Granger Causality. Test determines if stock market index is related to another market index. It can also be used to forecast other time series. Null hypothesis for granger causality test is that there is no causality among selected stock market indices. Null hypothesis is rejected when $p$ value is less than 0.05 which exhibits that there is granger causality in two market indices. The upside of granger causality test is that it only shows if causality exists. However, its drawback is that it does not show the coefficient of granger causality. The results of above table show that Canadian stock market index shares a unidirectional relationship with market indices of Mexico, USA (NASDAQ), USA (NYSE), Panama and Trinidad \& Tobago. It means that a change in Canadian stock market index would bring a change in the stock market indices of above-mentioned countries and stock markets. There is also granger causality between the stock market indices of Mexico and Canada. These two stock markets share bi-directional relationship with each other in short run. It is obvious from the table that some market indices share a unidirectional relationship with other stock market indices in short run. It means that there exists a short run relationship between two market indices.

\section{CONCLUSIONS}

This paper examines the international linkages among the stock markets in North and South America. These stock markets present significant investment opportunities based on international diversification strategy. The stock markets are not highly correlated which means that they are not dependent upon each other and present a portfolio diversification opportunity. The results of multivariate and pairwise co-integration also support diversification opportunities. Apart from few stock markets, most of the stock market indices are not highly cointegrated with each other which lend the support for portfolio diversification. The results of Granger causality test are also supporting the diversification opportunities in the selected stock markets of Americas. Future research should focus on diversification opportunities in the stock markets of Asia and 
Europe. A better understanding of the linkages between selected stock markets in Americas is of great interest for foreign portfolio investment decision-making processes. Moreover, the textile sector is strongly influenced by stock market dynamics. Investment opportunities can lead to significant gains based on the implementation of efficient diversification strategies.

As a future direction of research, we will analyse the impact of the Covid-19 pandemic on the apparel and textile industry in Africa and Asia. In this regards, Batool et al. [40] argued that pandemics generate economic misery so countries must use rapid digitization in the context of the COVID-19 crisis.

\section{ACKNOWLEDGMENTS}

This work was supported by the grant POCU $380 / 6 / 13 / 123990$, co-financed by the European Social Fund within the Sectorial Operational Program Human Capital 2014-2020.

\section{REFERENCES}

[1] Bessler, D.A., Yang, J., The structure of interdependence in international stock markets, In: Journal of international money and finance, 2003, 22, 2, 261-287

[2] Singh, V., Li, B., Roca, E., Global and regional linkages across market cycles: evidence from partial correlations in a network framework, In: Applied Economics, 2019, 51, 33, 3551-3582

[3] Vo, X.V., Ellis, C.,International financial integration: Stock return linkages and volatility transmission between Vietnam and advanced countries, In: Emerging Markets Review, 2018, 36, 19-27

[4] Chen, G.M., Firth, M., Rui, O.M.,Stock market linkages: evidence from Latin America,In: Journal of Banking \& Finance, 2002, 26, 6, 1113-1141

[5] Spulbar, C., Trivedi, J., Birau, R., Investigating abnormal volatility transmission patterns between emerging and developed stock markets: a case study, In: Journal of Business Economics and Management, 2020, 21, 6, 1561-1592, https://doi.org/10.3846/jbem.2020.13507

[6] Xu, J., Liu, Y., Yang, L., A Comparative Study of the Role of China and India in Sustainable Textile Competition in the U.S. Market under Green Trade Barriers, In: Sustainability, 2018, 10, 1348; doi:10.3390/su10051348

[7] Kabir, S.M.F., Chakraborty, S., Hoque, S.M.A., Mathur, K., Sustainability Assessment of Cotton-Based Textile Wet Processing, In: Clean Technology, 2019, 1, 232-246

[8] Nawab, Y.,Textile Engineering: An introduction, De Gruyter GmbH \& Co KG: Berlin, Germany, 2016

[9] Olaru, S., Popescu, G., Anastasiu, A., Mihăilă, G., Săliștean, A., Innovative concept for personalized pattern design of safety equipment, In: Industria Textila, 2020, 71, 1, 50-54, http://doi.org/10.35530/lT.071.01.1620

[10] Săliştean, A., Toma, D., Olaru, S., Niculescu, C., Integrated UAS system - Single skin textile wing, In: Industria Textila, 2019, 70, 5, 426-429, http://doi.org/10.35530/IT.070.05.1616

[11] Markowitz, H., Portfolio selection, In: The journal of finance, 1952, 7, 1, 77-91

[12] Levy, H., Sarnat, M., International diversification of investment portfolios, In: The American Economic Review, 1970, 60, 4, 668-675

[13] Grubel, H.G., Fadner, K., The interdependence of international equity markets, In: The Journal of Finance, 1971, 26, 1, 89-94

[14] Bodie, Z., Kane, A., Marcus, A.J.,Investments, 4th Edition, McGraw Hill: Singapore, 1999

[15] Yildirim, R., Masih, M.,Investigating International Portfolio Diversification Opportunities for the Asian Islamic Stock Market Investors, MPRA Paper 90281, University Library of Munich, Germany, 2018

[16] Phylaktis, K., Ravazzolo, F.,Stock market linkages in emerging markets: implications for international portfolio diversification, In: Journal of International Financial Markets, Institutions and Money, 2005, 15, 2, 91-106

[17] Maldonado, R., Anthony, S.,International portfolio diversification and the inter-temporal of international stock market relationships 1957-1978, In: Financial Management, 1981, 10, 54-63

[18] Ripley, D., Systematic elements in the linkage of national stock market indices, In: The Review of Economics and Statistics, 1973, 15, 356-361

[19] Panton, D.B., Parker, V.L., Joy, O.M., Comovements of international equity markets: A Taxonomic approach, In: ournal of Financial and Quantitative Analysis, 1976, 11, 415-432

[20] Trivedi, J., Spulbar, C., Birau, R., Mehdiabadi, A., Modelling volatility spillovers, cross-market correlation and comovements between stock markets in European Union: an empirical case study, In: Business, Management and Economics Engineering, 2021, 19, 1, 70-90, https://doi.org/10.3846/bmee.2021.13588

[21] Arshanapalli, B., Doukas, J., International stock market linkage: Evidence from the pre- and post-October 1987 period, In: Journal of Banking and Finance, 1993, 17, 193-208

[22] Corhay, A., Rad, A., Urbain, J.,Long-run behavior of Pacific-Basin stock prices, In: Applied Financial Economics, 1995, 5, 11-18

[23] Cheung, Y.L., Mak, S.C.,A Study of the international transmission of stock market fluctuation between the developed markets and the Asian-Pacific markets, In: Applied Financial Economics, 1992, 2, 1-5

[24] DeFusco, R.A., Geppert, J.M., Tsetsekos, G.P., Long-run diversification potential in emerging stock markets, In: Financial Review, 1996, 31, 343-363 
[25] Korajczyk, R.A.,A measure of stock market integration for developed and emerging markets, In: The World Bank Economic Review, 1996, 10, 2, 267-289

[26] Ghosh, A., Saidi, R., Johnson, K.H., Who moves the Asia-Pacific stock markets - US or Japan? Empirical evidence based on the theory co-integration, In: The Financial Review, 1999, 34, 159-170

[27] Tuluca, S.A., Burton, Z., The effects of the Asian crisis on global equity markets, In: The Financial Review, 2001, 36, 125-142

[28] Wong, W.K., Penm, J., Terrell, R.D., Ching, K.Y., The relationship between stock markets of major developed countries and Asian emerging markets, In: Journal of Applied Mathematics \& Decision Sciences, 2004, 8, 4, 201-218

[29] Antonio, G.P.,Assessing European stock markets (co) integration, In: Economics Letters, 2003, 78, 197-203

[30] Fama, E.F., The behavior of stock market prices, In: Journal of Business, 1965, 38, 1, 34-105

[31] Rahim, M.A.,Masih, M., Portfolio diversification benefits of Islamic investors with their major trading partners: Evidence from Malaysia based on MGARCH-DCC and wavelet approaches, In: Economic Modelling, 2016, 54, 425-438

[32] You, L., Daigler, R.T., Is international diversification really beneficial?, In: J. Bank. Financ.,2010, 34, 163-173

[33] Engle, R.F., Sheppard, K., Theoretical and empirical properties of dynamic conditional correlation multivariate GARCH, In: National Bureau of Economic Research, 2001, Working Paper 8554, Available at: http://www.nber.org/papers/w8554.pdf [Accessed on December 2019]

[34] Capiello, R., Engle, R.F., Sheppard, K.,Asymmetric dynamics in the correlations of global equity and bond returns,In: European Central Bank Working Paper Series, 2003, Working Paper No. 204.

[35] Bouri, E., Jain, A.,Biswal, P.C., Roubaud, D.,Cointegration and nonlinear causality amongst gold, oil, and the Indian stock market: Evidence from implied volatility indices, In: Resources Policy, 2017, 52, 201-206

[36] Cheong, C.W.,A sectoral efficiency analysis of Malaysian stock exchange under structural break, In: American Journal of Applied Sciences, 2008, 5, 1291-1295

[37] Alam, N., Arshad, S., Rizvi, S., Do Islamic stock indices perform better than conventional counterparts? An empirical investigation of sectoral efficiency, In: Review of Financial Economics, 2016, 31, 108-114

[38] Spulbar, C., Birau, R., Testing weak-form efficiency and long-term causality of the R.I.P.H emerging capital markets, In: International Journal of Business Quantitative Economics and Applied Management Research ISSN 2349-5677, 2018, 5, 2, 1-19, Available at: http://ijbemr.com [Accessed on January 2020]

[39] Zulfiqar, A.I., Ejaz, A., Spulbar, C., Birau, R., Nethravathi, P.S.R., Measuring the Impact of Governance Quality on Stock Market Performance in Developed Countries, In: Economic Research-Ekonomska Istraživanja, 2020, 33, 1, 3406-3426, https://www.tandfonline.com/doi/full/10.1080/1331677X.2020. 1774789.

[40] Batool, M., Ghulam, H., Hayat, M.A., Naeem, M.Z., Ejaz, A., Imran, Z.A., Spulbar, C., Birau, R., Gorun, T.H., How COVID-19 has shaken the sharing economy? An analysis using Google trends data, In: Economic ResearchEkonomska Istraživanja, 2020, https://www.tandfonline.com/doi/full/10.1080/1331677X.2020.1863830

\section{Authors:}

RAMONA BIRAU ${ }^{1}$, CRISTI SPULBAR ${ }^{2}$, AJMAL HAMZA $^{3}$, EJAZ ABDULLAH ${ }^{4}$, ELENA LOREDANA MINEA ${ }^{2}$, ALI IMRAN ZULFIQAR ${ }^{5}$, MIHAI OVIDIU CERCEL ${ }^{6}$

${ }^{1}$ C-tin Brancusi University of Targu Jiu, Faculty of Education Science, Law and Public Administration, Romania

2University of Craiova, Faculty of Economics and Business Administration, Craiova, Romania e-mail: cristi_spulbar@yahoo.com, loredanaelenaminea@gmail.com

3 University of Waikato, New Zealand

e-mail: ajmalhamza1989@gmail.com

${ }^{4}$ Canada and Augustana Campus - University of Alberta, MacEwan University, Department of Anthropology,

Economics and Political Science, Canada e-mail: ejazabdullah03@gmail.com

5 University of Lahore, Pakistan

e-mail: zulfiqaraliimran05@gamail.com

${ }^{6}$ National University of Political Studies and Public Administration, Bucharest, Romania e-mail: mihai.cercel@dri.snspa.ro

\section{Corresponding author:}

RAMONA BIRAU

e-mail: ramona.f.birau@gmail.com 